\title{
Influence of Exchange Rate on the Economic Growth in the Turkish Economy
}

\author{
Özcan Karahan \\ Bandırma Onyedi Eylül University \\ Faculty of Economics and Political Sciences, Economics Department \\ Merkez Yerleşkesi, 10200, Bandırma-Balıkesir, Turkey \\ E-mail: okarahan@bandirma.edu.tr
}

\begin{abstract}
The traditional view asserts that there is a positive relationship between the foreign exchange rate and economic growth. So much so that an increase in foreign exchange rates enhances the net export volume and thus positively affects economic growth due to the increasing total demand. However, structural economists argue that there is an inverse relationship between the exchange rate and economic growth. Especially in developing countries, the input structure of production depends on imported capital and intermediate goods, so an increase in exchange rates makes import production inputs more expensive and thus negatively affects economic growth. Turkey, leaving foreign exchange rate free float since 2002, has implemented the Inflation Targeting (IT) regime as the monetary policy. Therefore, Turkey has a real experience to analyse the role of exchange rate changes on economic growth. Accordingly, in our study, using the quarterly data between 2002-Q1 and 2019-Q1, the relationship between exchange rate and economic growth was examined by employing Johansen cointegration test, Granger causality test and Innovation Accounting Techniques. Empirical findings suggest that there is a negative causal relationship between exchange rates and economic growth, as claimed by structuralist economists. In terms of policy implications, it can be argued that, even under the inflation targeting regime in Turkey, both price and exchange rate stability should be provided together.
\end{abstract}

Keywords: cointegration, exchange rate, economic growth, Granger causality, time-series model, vector error correction model

JEL codes: $F 31, F 43, C 22$

\section{Introduction}

The economic effects of the exchange rate changes are among the most controversial issues in the literature. Particularly, the effect of exchange rate changes on economic growth has become one of the most important research topics over the past decades. The traditional view argues that there is a positive relationship between exchange rate changes and economic growth. Accordingly, depreciation of local currency after an increase in the exchange rate, by influencing the relative prices of domestic and foreign goods, promotes exports while decreasing imports. In other words, the depreciation of the local currency both converts the demands of foreigners into the country and directs the import 
demands of the indigenous to the local products. As a result, increases in exchange rates support economic growth by encouraging net exports. That means devaluation can be proposed as an effective policy tool that can be used to stimulate economic growth. Contrarily, structuralist economists argue that the devaluation policy will have a negative impact on the economies of developing countries. Because one of the most important structural problems in developing countries' economies is the phenomenon of foreign dependency. Most of the inputs used by such countries especially in their production processes are provided through imports. Most of the inputs used by such countries especially in their production processes are provided through imports. For this reason, increases in the exchange rate will augment imported input costs such as machinery and intermediate goods used in the production process. Thus, increasing production costs due to the depreciation of the domestic currency can have a negative impact on the output level.

In order to make a contribution to the debate in the literature indicated above, this study aims to test the arguments that are put forward by classical and structuralist economists related to the link between exchange rate and economic growth, using data belonging to Turkey's economy. Turkey provides a genuine experience to be analyzed as regards the impact of the exchange rate on economic growth because, following the economic crisis in 2001, the exchange rate in Turkey was allowed to float within the framework of Inflation Targeting Regime. In our study, the relationship between exchange rate and economic growth has been analyzed using the Johansen cointegration test, Granger causality test and Innovation Accounting Techniques for the data between 2002-Q1 and 2019-Q1. The rest of the paper is arranged as follows. Section 2 reviews the related empirical literature. Section 3 explains the data and methodology. Section 4 presents the empirical results. The final section concludes and makes some policy implications.

\section{Literature Review}

In the literature, there is plenty of empirical research that examined the relationship between the level of the exchange rate and economic growth. Most of this empirical research has documented a strong causality relationship between the level of the exchange rate and economic growth. Indeed, there seems to be a wide acceptance that the direction of causality runs from exchange rate to economic growth. However, there is no agreement on whether this causality relationship from exchange rate to economic growth is positive or negative. In other words, whether the impact of exchange rate on economic growth is positive or negative is quite a controversial issue. In general terms, the conventional approach asserts that the rising exchange rate positively affects economic growth while the structuralist view argues that the rising exchange rate brings about a contraction in the economy.

According to the conventional view, an increase in the exchange rate creates a positive impact on economic growth via enhancing the volume of net export. The main reason for the increase in output level with the expansion of net exports here 
is the change in the relative prices of domestic and foreign goods after the increase in exchange rates. Namely, a depreciation of local currency decreases the prices of domestic goods while, at the same time, makes the prices of goods from abroad much more expensive. Thus, a depreciation of the exchange rate firstly increases the volume of net export and then the growth rate of the economy. That means devaluation can be used as a policy tool promoting economic growth. Indeed, mainstream studies have produced many econometric results concerning the positive correlation between the exchange rate increase and net export or economic growth. Accordingly, the positive impact of currency depreciation on economic growth has been widely documented in the literature.

Domaç (1997), for the period 1960-1990, examined the relationship between exchange rate and economic growth in Turkey. Using regression analysis, he found that unexpected devaluations had a positive effect on output. Thus, the author determined that the contractionary devaluation hypothesis is not valid in Turkey. Narayan and Narayan (2007) investigated the effects of devaluation for the Fiji economy between 1970 and 2000. They employed the co-integration method and found that the devaluation in the short- and long-term lead to a widening effect for the output level. More specifically, it was indicated that $10 \%$ devaluation increased the output by $3.3 \%$. Tarawalie (2010) provided empirical estimates of the relationship between the real exchange rate and economic growth in Sierra Leone, employing the Johansen cointegration technique for the period 19990Q1-2006Q4. The results indicated that the real exchange rate had a positive effect on output growth. Specifically, a depreciation of the real exchange rate increased the output growth in Sierra Leone. Di Nino et al. (2011) analyzed the connection between exchange rate and economic growth in Italy. They concluded that there is a positive relationship between undervaluation and economic growth for a dataset covering the period 1861-2011. In addition, the authors also showed that undervaluation supported growth by increasing exports, especially in high-productivity sectors. Chen (2012) focused on the role of the exchange rate in economic growth and the convergence of growth rates in Chinese provinces. Data set between 1992 and 2008 for 28 provinces were tested with dynamic panel data estimation. He found that the real exchange rate increase had a positive effect on the economies of provinces. Aman et al. (2013) investigated the relationship between exchange rate and economic growth in Pakistan for the period 1976-2010 by employing threestage least square techniques. They showed that the exchange rate has a positive impact on economic growth through promoting export and import substitute industry. Obansa et. al (2013) examined the impact of exchange rate on the Nigerian economic growth for the period of 1970-2010. The result indicated that the exchange rate had a strong positive impact on economic growth. Thus, they found evidence that economic growth is significantly associated with real exchange rate depreciation.

When multi-country studies are examined, there are many studies showing a positive effect of the exchange rate on economic growth. Rodrik (2008) examined the relationship between economic growth and real exchange rates using a data 
set from 188 countries between 1950 and 2004. Rodrik found a systematic positive relationship between growth and depreciation in the real exchange rate. However, the increase in the depreciation of the real exchange rate only caused economic growth in some developing countries. According to him, this relationship does not apply to developed rich country economies. Missio et. al (2015) empirically analysed the relationship between real exchange rate and growth rate of output for a broad sample of 63 developing countries from 1978 to 2007. They found that maintaining a competitive level of the real exchange rate had a positive effect on growth rate. This result means that depreciation of a currency can affect the longterm growth of an economy via an increase in its income elasticity of the demand for exports. Finally, Habib et al. (2017) analysed the impact of movements in the real exchange rate on economic growth based on five-year average data for a panel of over 150 countries in the post-Bretton Woods period. They determined that a real depreciation raised the annual real GDP growth. Thus, the results revealed the broader effects of devaluation on economic growth for developing countries. As seen in the literature above, many studies have found that the rising exchange rate has a positive impact on the economy and thus have supported the devaluation policy for economic growth. However, structuralist economists argue that the rising exchange rate has a restrictive effect on economic growth, especially in developing countries. Therefore, the devaluation policy creates a confining impact on the growth of developing economies (Bird and Rajan 2004:143-144). The negative impact of increases in exchange rates on economic growth arises from the restrictive effects on the imported input the production structure of developing countries is mainly dependent on. Therefore, the increases in the exchange rate create a negative impact on economic growth by decreasing the imports of raw materials, intermediate goods and investment goods. That's why the devaluation policy produces positive outcomes in some developed countries while it results in negative consequences for the economic growth in developing countries (Hallwood and Macdonald, 2003: 421). Furthermore, it has been argued that import affects growth in developing countries by transferring new knowledge or technology from abroad. Thus, import affects economic growth in developing countries by not only providing production input but also enhancing domestic technological capability. Imported machinery and intermediate goods generate the channels for the diffusion of new technology among countries. Therefore, it is clear that imports have an impact on developing countries' growth by raising the technological capacity of the economy by transferring new knowledge. The important role of imports in technological diffusion has been extensively documented in the literature (Lee 1995; Mazumdar 2001; Keller 2004). Consequently, some perspectives developed by structural economists on emerging economies lead them to make different conclusions about the relationship between the exchange rate and economic growth. So much so, the rising exchange rate, which leads to restricted imports in developing countries, reduces economic growth by reducing both production input and technology transfer. 
In the literature, many studies focusing on developing countries have also empirically shown that depreciation of the local currency caused a contraction. Firstly, Cottani et al (1990) used the analysis of cross-section regression for 24 developing countries over 1960-1983 in order to test the hypothesis that appreciation of local currency hinders growth. Empirical findings showed that there wa a statistically significant negative relationship between the level of the exchange rate and output level. Bahmani-Oskooee et al. (2002) examined the transfer mechanism from the exchange rate to economic growth in five Asian countries using the monthly data between 1976 and 1999. The empirical results of Johansen cointegration and Granger causality tests indicated that the depreciation of local currencies had a negative impact on economic growth in Asian countries. Thapa (2002) analyzed the econometric relationship between the real exchange rate and economic activities in Nepal using annual data from 1978 to 2000. The estimated ECM regression equation showed that the real exchange rate had a contractionary effect on economic growth. Galindo and Montero (2005) investigated the causality relationship from exchange rate to economic growth by using panel data relating to 9 Latin American countries. Empirical results indicated that rising exchange rate in the Latin American countries which have a high foreign debt ratio negatively affected economic growth. Yiheyis (2006) investigated the interaction among the exchange rate and economic growth in 20 African countries for the term 19811999. The results of unbalanced panel data analysis indicated that the depreciation of local currencies created a shrinking effect on economic growth. This finding implies that currency depreciation, by increasing the price in the domestic currency of imported intermediate inputs used in the production process, feeds through production costs, thus causing a restriction on the production process. Blecker and Razmi (2008) examined the impact of devaluation on economic growth in 17 developing countries for the period 1983-2004. Results of the dynamic panel data analysis (Generalised Method of Moments) showed a negative relationship between the exchange rate and economic growth. As a result, the authors emphasized that the contractionary effect of devaluation for developing countries was compared to industrialized countries.

Related to more recent studies advocating the argument of structural economists, Vaz and Baer (2014) employed a panel model using unbalanced panel data covering 1995-2008 for a sample of 39 countries in Latin America and proved a negative impact of exchange rate on output. Thus, they showed that depreciation of the currency in Latin American countries caused a nominal cost increase in the production process and hence decreased economic growth rate rather than raised it. Çelik et al. (2017) investigated the transfer mechanism from the exchange rate to economic growth via panel data analysis using cross-sectional data between 1995 and 2014 for 12 transition economies in Eastern Europe and Middle Asia. The results of the study showed that an increase in exchange rate resulted in an economic downturn. However, they also indicated that real exchange rate movements did not turn out to be the major variable in explaining economic growth. Finally, Ribeiro et al (2019), by taking into account the structural features 
of the developing economies, examined the relationship between real exchange rate and economic growth. The sample consisted of 54 developing countries and covered the period 1990-2010. The empirical result showed that the impact of undervaluation on economic growth in developing countries was negatively signed.

\section{Data and Methods}

The aim of this section is to examine the relationship between nominal exchange rate and economic growth using data between 2002-Q1 and 2019-Q1. The variables of the nominal exchange rate (ER) and economic growth rate (EG) are sourced from Electronic Data Delivery System in Central Bank of the Republic of Turkey. The empirical analysis begins by checking the stationary statute of data set using Dickey and Fuller and Phillips-Perron Tests. Then, the long-run relationship between inflation and interest rate is analyzed using Johansen (1988) Cointegration Test. Finally, we examine the causality relationship between inflation and interest rate by operating Granger (1988) Causality Test based on Error Correction Model.

The stationary analyses of the variables were performed with the Augmented Dickey-Fuller (ADF) and Philips Perron (PP) unit root tests. The constant model of the ADF unit root test developed by Dickey and Fuller (1981) can be shown in Equation 1 . Test results determined by the estimation of these model are evaluated in terms of critical values of MacKinnon and the null hypothesis $\left(H_{0}: \alpha=0\right)$ is tested against the alternative hypothesis $\left(H_{1}: \alpha \neq 0\right)$. The null hypothesis indicates that the series is not stationary, while the alternative hypothesis suggests that the series is stationary.

$$
\Delta Y_{t}=\beta_{0}+\alpha Y_{t-1}+\sum_{i-1}^{m} \Delta Y_{t-i}+\varepsilon_{t}
$$

The unit root test developed by Phillips-Perron (1988) is based on the model determined in Equation 2. In this equation, T determines the number of observation while $t$ indicates time. Test results determined by estimation of these models are evaluated in terms of critical values of MacKinnon. The null hypothesis $\left(H_{0}: \lambda=0\right)$ is tested against the alternative hypothesis $\left(H_{1}: \lambda<0\right)$. The null hypothesis states that the series contains the unit root while the alternative hypothesis states that the series does not contain a unit root.

$$
\Delta Y_{t}=\delta_{0}+\lambda Y_{t-1}+\delta_{1}(t-T / 2)+u_{t}
$$

The cointegration test developed by Johansen and Juselius (1990) is suitable for examining the long-term relationship between variables after determining that the data are stable at the same level. This method makes an analysis of cointegration over the system of simultaneous equations generated using variables that become stable at the same time when the difference is taken. In the framework of this methodology, a VAR (Vector Autoregressive) Model with $\mathrm{p}$ degree in Equation 4 is operated. 


$$
Y_{t}=\mu+A Y_{t-1}+\ldots \ldots+A_{p} Y_{t-p}+e_{t}
$$

Equation 3 can be rearranged as in equation 4 by taking the first difference.

$$
\Delta Y_{t}=\mu+\Pi Y_{t-1}+\sum_{i=1}^{p-1} \Gamma_{i} \Delta Y_{t-i}+e_{t}
$$

In Equation 4, $\Pi$ is the parameter indicating the long term relation. Thus, the cointegration hypothesis is analyzed through the equation which is $\Pi=a \beta$. So, $a$ and $\beta$ (pxr) represent a two-dimensional matrix. The matrix a shows the rate of improvement of the deviations from the long-run equilibrium of the variables as $\beta$ denotes the cointegration vector showing the long-term effects of the variables in the equilibrium relations. The number of cointegration vectors is examined in the framework of Trace Statistics and Maximum-Eigen Statistics. Thus, both tests investigate long term associations by determining how many cointegrated vectors are among the variables.

Trace Statistics can be calculated from the formula indicated in Equation 5. Here, the null hypothesis $\left(H_{0}: r \leq m-1\right)$ is tested against the alternative hypothesis $\left(H_{1}: r \geq m\right)$.

$$
\lambda_{\text {trace }}(r)=-T \sum_{i=r+1}^{m} \ln \left(1-\lambda_{i}\right)
$$

Max-Eigen Statistics can be calculated from the formula indicated in Equation 6. Here, the null hypothesis $\left(H_{0}: r \leq m-1\right)$ is tested against the alternative hypothesis $\left(H_{1}: r \geq m\right)$.

$$
\lambda_{\max }(r, r+1)=-T \ln \left(1-\lambda_{r+1}\right)
$$

If the cointegration relation is found between the variables used in the analysis, then the VECM (Vector Error Correction Model) method should be used when the dynamic effects are examined at the next stage. Accordingly, the models to be used in the causality test developed by Granger (1988) are defined in Equations 7 and 8 below, including the error correction term.

$$
\begin{aligned}
& \Delta Y_{t}=\beta_{0}+\sum_{i=1}^{m} \alpha_{i} \Delta Y_{t-i}+\sum_{k=1}^{m} \beta_{k} \Delta X_{t-k}+\lambda_{1} E C T_{t-1}+u_{t} \\
& \Delta X_{t}=\mathrm{u}_{0}+\sum_{i=1}^{m} \mathrm{u}_{i} \Delta X_{t-i}+\sum_{k=1}^{m} \delta_{i} \Delta Y_{t-k}+\lambda_{2} E C T_{t-1}+v_{t}
\end{aligned}
$$

In equations, the coefficients of the error correction term (ECT) $\lambda_{1}$ and $\lambda_{2}$ show the rotational speed of $X$ and $Y$ variables to equilibrium relation. Error correction coefficients are expected to be negative and statistically significant for the validity of the model examined. In the framework of the Granger causality test, whether the $a$ and $\delta$ coefficients in the equations are meaningful is tested by the standard F-test. Accordingly, by Equation 7, Y Granger causes $X$ if the null of either $\sum_{\mathrm{k}=1}^{\mathrm{m}} \beta_{\mathrm{k}}=$ 0 or $\lambda_{1}=0$ is rejected. On the other hand, by Equation $8, X$ Granger causes $Y$ if $\lambda_{2}$ is significant and $\sum_{\mathrm{k}=1}^{\mathrm{m}} \delta_{\mathrm{i}}$ are jointly significant. Finally, in terms of the results relating 
to causality relationship between $X$ and $Y$, it is estimated the coefficients of VECM in Equation 7 or Equation 8 in order to determine short-run dynamics between the variables examined.

Besides the estimation of vector error correction model, Innovation Accounting Techniques including Impulse Response Function and Variance Decomposition can also be performed in order to investigate the short-run relationship between the variables and assess the adjustments towards long-run equilibrium. Analysis of Impulse Response Function allows us to examine the dynamic effects of one variable's shock on other variables. The Impulse Response Function analysis traces the effect that a one-standard-deviation-shock to one of the endogenous variables has on current and future values of all variables in the system. On the other hand, analysis of Variance Decomposition tells us the proportion of the movements due to its own shocks to the other variable. As a result, analyses of variance decomposition are a tool used for measuring the effects of other variables on the relevant variable. In other words, this analysis determines how much of the estimated error variance of a variable after a unit of time is explained by changes in other variables.

\section{Results and Discussion}

In this section, we empirically examine the relationship between exchange rate and economic growth in Turkey by Johansen Cointegration Test and Granger Causality Test based on Error Correction Model. Before running the econometric analysis of the model, we test whether time series used in the model is stationary or not. Accordingly, we check whether time series of economic growth rate (EG) and exchange rate (ER) are stationary by using Augmented Dickey-Fuller (ADF) and Philips Peron (PP) tests. Both tests are widely preferred for unit root analysis in the literature. Table 1 presents the results of unit root tests. Findings show that all variables are not stationary at level. However, by first differentiation, all series become stationary since the calculated test statistics exceed the critical values. In conclusion, both economic growth (EG) and exchange rate (ER) series are integrated of the same order at I (1).

Table 1 Results of Unit Root Tests

\begin{tabular}{lcccc}
\hline & $\begin{array}{c}\text { ADF test } \\
\text { (Augmented Dickey Fuller) }\end{array}$ & $\begin{array}{c}\text { PP test } \\
\text { (Philips Peron) }\end{array}$ \\
\hline \hline Variables & Level & First Difference & Level & First Difference \\
\hline EG & -3.8723 & $-6.1267 *$ & -2.1256 & $-5.1257^{* *}$ \\
\hline ER & -2.5812 & $-5.3598 *$ & -1.5711 & $-4.1823^{* *}$ \\
\hline
\end{tabular}

Note: $*$ and $* *$ indicate the significance level at $1 \%$ and $5 \%$, respectively. Maximum lag length is specified by considering Akaike Information Criterion (1).

Source: Author's calculation. 
After determining that both series of the exchange rate (ER) and economic growth (EG) are integrated of the same order at I (1), we employ Johansen cointegration test in order to investigate the long-run relationship between the variables. The results of Johansen Cointegration analysis including trace and Maximum Eigenvalue Statistics are presented in Table 2. Results show that the computed value of both Trace Statistic and Max-Eigen statistic are more than the critical value at $5 \%$ level of significance. Therefore, the null hypothesis that there is no co-integrating vector was rejected. Thus, the results of both cointegration test imply that there is a longrun relationship between exchange rate and economic growth in Turkey.

Table 2 Johansen Cointegration Tests Results

\begin{tabular}{ccccc}
\hline \multirow{2}{*}{$\begin{array}{c}\text { Null } \\
\text { Hypothesis }\end{array}$} & \multicolumn{2}{c}{ Trace Statistics } & \multicolumn{2}{c}{ Maximum Eigenvalue Statistics } \\
\cline { 2 - 5 } & $\begin{array}{c}\text { Test } \\
\text { Statistic }\end{array}$ & $\begin{array}{c}\text { \% 5 } \\
\text { Critical } \\
\text { Value }\end{array}$ & $\begin{array}{c}\text { Test } \\
\text { Statistic }\end{array}$ & $\begin{array}{c}\text { \% 5 } \\
\text { Critical } \\
\text { Value }\end{array}$ \\
\hline \hline$r=0$ & 28.1752 & 19.7432 & 22.3589 & 16.3467 \\
\hline$r \leq 1$ & 7.2651 & 8.7854 & 7.1256 & 8.7854 \\
\hline
\end{tabular}

Source: Author's calculation.

Given the long-run relationship among the variables, the Granger causality test based on the VECM (Vector Error Correction Model) has been employed in order to detect the direction of the relation between the variables. The results of Granger causality test are presented in Table 3. According to the results, we reject the null hypothesis that exchange rate (ER) does not Granger cause economic growth rate (EG). Thus, findings reveal that causality runs from the exchange rate (ER) to economic growth (EG) while the reverse causation is not confirmed.

Table 3 Granger Causality Test

\begin{tabular}{lccc}
\hline \multicolumn{1}{c}{$\begin{array}{c}\text { Null } \\
\text { Hypothesis }\end{array}$} & F-Statistic & p-Value & Decision \\
\hline \hline ER does not Granger cause EG & $3.9856^{*}$ & 0.0110 & Reject \\
\hline EG does not Granger cause ER & 0.7823 & 0.5123 & Not Reject \\
\hline
\end{tabular}

Note: * indicates the significance level at $5 \%$. Maximum lag length is specified by Akaike Information Criterion (1).

Source: Author's calculation.

In order to illustrate the short-term dynamics between exchange rate and economic growth, the results of VECM estimation are presented in Table 4. The coefficient of the error correction term is statistically significant and negative as we expected. Findings also indicated that the exchange rate affects economic growth negatively as confirmed by the sign of the related coefficient $\left(\Delta \mathrm{ER}_{\mathrm{t}-1}\right)$. 
Table 4 Estimation Results of Vector Error Correction Model

\begin{tabular}{cccc}
\hline Variables & Coefficient & t Value & Probability \\
\hline \hline Constant & $0.521^{* *}$ & 1.649 & 0.014 \\
\hline $\mathrm{EC}_{\mathrm{t}-1}$ & $-0.371^{*}$ & -3.195 & 0.011 \\
\hline$\Delta \mathrm{ER}_{\mathrm{t}-1}$ & $-0.187^{* *}$ & -2.078 & 0.000 \\
\hline$\Delta \mathrm{EG}_{\mathrm{t}-1}$ & $0.589 *$ & 3.841 & 0.000 \\
\hline
\end{tabular}

Note: *,** indicates the significance level at $1 \%$ and $5 \%$, respectively.

Source: Author's calculation.

Finally, in order to check the robustness of our results, we also examined the effect of the exchange rate on the economic growth in Turkey by using the Innovation Accounting Techniques including Impulse Response Function and Variance Decomposition. In the framework of Impulse Response Function analysis, Figure 1 presents the response of economic growth to shock from the exchange rate. Economic growth was found to respond negatively to a shock in the exchange rate from the first to the fourth term, and then the impact disappears. The results of variance decomposition analysis related to the economic growth are presented in Table 5. The findings suggest that the explanatory power of economic growth on itself goes on declining while exchange rate gains more explanatory power. Exchange rate explains $25.35 \%$ of economic growth variation by the 10 steps ahead of time horizon. Thus, the results of Innovation Accounting Techniques also suggest that exchange rate has a significant negative impact on the economic growth in Turkey.

Figure 1 Response of Economic Growth to Shock from Exchange Rate

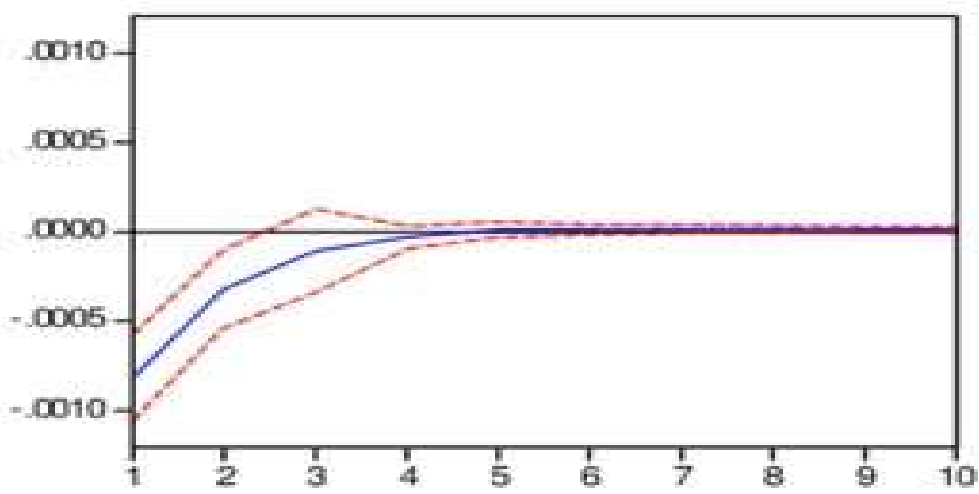

Source: Author's construction based on calculations. 
Table 5 Variance Decomposition of Economic Growth

\begin{tabular}{ccc}
\hline Periods & $\begin{array}{c}\text { Economic } \\
\text { Growth }\end{array}$ & Exchange Rate \\
\hline 1 & 78.34 & 21.66 \\
\hline 2 & 78.01 & 21.98 \\
\hline 3 & 77.56 & 22.44 \\
\hline 4 & 76.90 & 23.10 \\
\hline 5 & 76.29 & 23.71 \\
\hline 6 & 75.86 & 24.13 \\
\hline 7 & 75.59 & 24.41 \\
\hline 8 & 75.11 & 24.89 \\
\hline 9 & 74.98 & 25.01 \\
\hline 10 & 74.65 & 25.35 \\
\hline
\end{tabular}

Source: Author's calculation.

Overall, empirical results indicate that there is unidirectional negative causality from exchange rate to economic growth. This finding supports the structuralist view asserting that depreciation of local currency or an increase in the exchange rate has a contractionary impact on economic growth. It seems that depreciation of Turkish Lira restricts imports that create the appropriate conditions for economic growth by providing machinery, equipment and raw materials needed as the production inputs. In terms of policy implementation, empirical findings also give significant insights for the effectiveness of Inflation Targeting Policy adopted in Turkey since 2002. According to this, since the exchange rate is one of the significant determinants of economic growth in Turkey, special importance should be given to exchange rate management under Inflation Targeting Regime. In other words, Inflation Targeting Policy in Turkey should fulfil a difficult task by successfully providing both price and exchange rate stability at the same time.

\section{Conclusions}

There are two different hypotheses in the literature about how the exchange rate affects economic growth in developing countries. Conventional view asserts that rising exchange rate causes export-led growth and thus promotes the profitability of the tradable sector and leads to an expansion of the share of tradable in domestic value-added. On the other hand, different perspectives developed by structural economists on developing economies argue an adverse relationship between exchange rate and economic growth. Currency depreciation, by increasing the price in the domestic currency of imported intermediate inputs used in the production process, feeds through production costs, thus causing a restriction on the production process. Motivated by these considerations, our paper seeks to contribute to the literature by examining the case of Turkey under inflation 
targeting regime. Accordingly, we examine the relationship between exchange rate and economic growth in Turkey using the Johansen co-integration test, Granger causality test and Innovation Accounting Techniques for the data from 2002Q1 to 2019 Q1.

Our results show that increases in the level of the exchange rate were associated with a reduction in output level. Thus, our findings provide an econometric confirmation for the structuralist view, which argues that the rise in the exchange rate causes a contraction in economic activity. That means it is not appropriate to think that depreciation of local currency causes export-led growth in Turkey which has a production structure based on the imported input. The most important policy implication from the findings indicates that there is a need for an exchange rate policy framework that complements the existing inflation targeting regime in Turkey. Instead of completely liberalizing the exchange rate in the framework of inflation targeting strategy adopted since 2002, policymakers in Turkey have to prevent the upside movements in the exchange rate by taking into consideration its negative effect on economic growth. In other words, the inflation targeting regime in Turkey can only be implemented successfully in the context of a broadbased monetary policy involving a complementary exchange rate policy.

\section{References}

Aman, Q., Ullah, I., Khan, M.I. and Khan, S. (2013). Linkages between Exchange Rate and Economic Growth in Pakistan, European Journal of Law and Economics. 44(1), pp. 157-164.

Bahmani-Oskooee, M., Chomsisengphet, S. and Kandil, M. (2002). Are Devaluations Contractionary in Asia. Journal of Post Keynesian Economics, 25(1), pp. 69-81.

Bird, G. and Rajan, R. S. (2004). Does Devaluation Lead to Economic Recovery or Economic Contraction? Theory and Policy with Reference to Thailand. Journal of International Development, 16, pp. 141-156.

Blecker, R.A. and Razmi, A. (2008). The Fallacy of Composition and Contractionary Devaluations: Output Effects of Real Exchange Rate Shocks in Semi Industrialised Countries. Cambridge Journal of Economics, 32(1), pp. 83-109.

Chen, J. (2012). Real Exchange Rate and Economic Growth: Evidence from Chinese Provincial data. PSE Working Papers, 2012-05, 127.

Cottani, J., Domingo, C. and Shahbaz, M. K. (1990). Real Exchange Rate Behaviour and Economic Performance in LDCs. Economic Development and Cultural Change, 39(1), pp. 61-76.

Çelik, T., Çelik B. and Barak, D. (2017). Real Exchange Rate and Economic Growth Relationship in Transition Economies. Suleyman Demirel University, The Journal of Faculty of Economics and Administrative Sciences, 22(3), pp. 877-890. 
Di Nino, V., Eichengreen, B. and Sbracia, M. (2011). Real Exchange Rates, Trade, and Growth: Italy 1861- 2011. Banca d'Italia Economic History Working Papers, No. 10.

Dickey, D.A. and Fuller W.A. (1981). Likelihood Ratio Statistics for Autoregressive Time Series with a Unit Root. Econometrica, 49(4), pp. 1057-1072.

Domaç, İ. (1997). Are Devaluations Contractionary? Evidence from Turkey. Journal of Economic Development, 22(2), pp. 145-163.

Galindo, A., A. Izquierdo and Montero, J. (2005). Real Exchange Rates, Dollarization and Industrial Employment in Latin America. Banco de España Working Paper, No: 0601.

Granger, C.W.J. (1988). Some Recent Developments in a Concept of Causality. Journal of Econometrics, 39(1-2), pp. 199-211.

Habib M. M., Mileva, E. and Stracca, L. (2017). The Real Exchange Rate and Economic Growth: Revisiting the case using External Instruments. Journal of International Money and Finance, 73, pp. 386-398.

Hallwood, C. P. and R. Macdonald (2003). International Money and Finance, Blackwell Publishing. ISBN: 0-631-20461-X.

Johansen, S. and Juselius, K. (1990). Maximum Likelihood Estimation and Inference on Cointegration with Application to the Demand for Money. Oxford Bulletin of Economics and Statistics, 52, pp. 169-210.

Keller, W. (2004). International Technology Diffusion. Journal of Economic Literature, 42, pp. 752-782.

Lee, J.-W. (1995). Capital Goods Imports and Long-run Growth. Journal of Development Economics, 48, pp. 91-110.

Mazumdar, J. (2001). Imported Machinery and Growth in LDCs. Journal of Development Economics, 65, pp. 209-24.

Missio, F. J., Jayme, G. F., Britto, G. and Oreiro, J. L. (2015). Real Exchange Rate and Economic Growth: New Empirical Evidence. Metroeconomica, 66(4), pp. 686714.

Narayan, P.K. and Narayan, S. (2007). Is Devaluation Expansionary or Contractionary? Empirical Evidence from Fiji. Applied Economics, 39, pp. 25892598.

Obansa, S. A. J., Okoroafor, O. K. D., Aluko, O. O. and Millicent Eze (2013). Percieved Relationship between Exchange Rate, Interest Rate and Economic Growth in Nigeria: 1970-2010. American Journal of Humanities and Social Sciences, 1(3), pp. 116-124.

Phillips, P.C.B. and Perron, P. (1988). Testing for a Unit Root in Time Series Regression. Biometrika, 75, pp. 335-346 
Ribeiro, R. S. M., McCombie, J. S. L. and Lima, G. T. (2019). Does Real Exchange Rate Undervaluation Really Promote Economic Growth? Structural Change and Economic Dynamics, 50, pp. 408-417.

Rodrik, D. (2008). The Real Exchange Rate and Economic Growth. Brookings Papers on Economic Activity, 2, pp. 365-412.

Tarawalie, A. B. (2010). Real Exchange Rate Behaviour and Economic Growth: Evidence from Sierra Leone. South African Journal of Economic and Management Sciences, 13(1), pp. 8-23.

Thapa, N. B. (2002). An Econometric Analysis of the Impact of the Real Effective Exchange Rate on Economic Activities in Nepal. Economic Review: Occasional Paper, 14, pp. 1-20.

Vaz, H. P. and Baer, W. (2014). Real Exchange Rate and Manufacturing Growth in Latin America. Latin American Economic Review, 23 (2), pp. 1-17.

Yihesis, Z. (2006). The Effects of Devaluation on Aggregate Output: Empirical Evidence from Africa. International Review of Applied Economics, 20(1), pp. 2145. 